\title{
Establishment of an in vitro culture of Pelargonium $\times$ domesticum cultivars characterized by different growth requirements
}

\author{
Ewa Hanus-Fajerska *, Agnieszka Mrzygeód, Alina Wiszniewska, \\ AleKsandra Koźmińska, Piotr StOlarczyK \\ Botany and Plant Physiology Unit, Institute of Plant Biology and Biotechnology, \\ Faculty of Biotechnology and Horticulture, University of Agriculture in Krakow, Kraków, Poland \\ *Corresponding author: e.hanus@ogr.ur.krakow.pl
}

\begin{abstract}
Experiments were carried out to develop micropropagation protocols for cultivars of hybrid origin which have been not cultivated via tissue culture. Proliferating cultures of Pelargonium $\times$ domesticum "Tip Top Duet" and "Black Knight" were obtained even if initially the number of excised aseptic nodal pieces was considerably reduced due to contamination with endogenic bacteria. The supplementation of a maintenance medium with either 100 or $200 \mathrm{mg} / \mathrm{l}$ peptone proved beneficial. The best propagation coefficient, exceeding 82 adventitious shoots from one initial microcutting, was obtained on a modified MS medium with an addition of $200 \mathrm{mg} / \mathrm{l}$ peptone and $0.5 \mathrm{mg} / \mathrm{l}$ adenine. The regenerated shoots readily developed new, anatomically properly formed leaves. In the plant material studied, the leaf epidermis produced glandular trichomata which were similar in structure to those observed in a standard cultivar.
\end{abstract}

Keywords: micropropagation, Pelargonium, plant tissue culture, Geraniaceae, peptone

\author{
Abbreviations \\ BA - benzyladenine \\ IAA - indole -3-acetic acid
}

IBA - indole-3-butyric acid

NAA - 1-naphtaleneacetic acid

PPFD - photosynthetic photon flux density

\section{Introduction}

The section Pelargonium L. Hér. (Geraniaceae) containing both aromatic and non-aromatic species is a typical element of the Cape Floristic Region. According to the findings of floristic studies, the family Geraniaceae is one of the most commonly represented in the region, in terms of the number of recognized taxons. Genus $P e$ largonium comprises about 250 species, of which almost sixty percent are endemic to Africa. About 160 species that belong to the Flora of Southern Africa (FSA) region have a wide distribution throughout the FSA area (van der Walt and Vorster, 1983; Bakker et al., 1999, 2000; Weng et al., 2012; Martinez-Cabrera and Peres-Neto, 2013). Specimens of numerous taxa are conspicuously tomentose, and frequently aromatic. Their leaves come in a variety of shapes and sizes. Some Pelargonium species, and their derived cultivars with beautiful five-petalled flowers - widely known as rose-scented geraniums or regal geraniums - are eagerly cultivated as popular indoor or outdoor ornamental plants (Mosina et al., 2014; Darras et al., 2015). Several other species from this genus are also valued as medicinally important plant materials (Saraswathi et al., 2011; Moyo and Van Staden, 2014). Extracts obtained from some of these are characterized by a high level of antimicrobial activity (Lis-Balchin and Deans, 1996). Numerous Pelargonium species are especially known as commercially important essential oil yielding aromatic crops (Rao et al., 1996; Rao, 2002; Nejad and Ismaili, 2013).

In commercial production, new cultivation technologies and healthy starting materials are of crucial importance (Murthy et al., 1996; Wojtania et al., 2004; Milošević et al., 2012). An in vitro culture provides an ideal opportunity to overcome those factors which could limit efficient propagation. Thus, mass production of the highest quality plant material is currently possible due to the 
exploitation of appropriate plant tissue and cell culture techniques. Some common approaches to in vitro regeneration technology for the members of genus Pelargonium have previously been described, including caulogenesis, somatic embryogenesis and formation of embryo-like structures (Mithila et al., 2001; Madden et al., 2005). Additionally, previous experiments have revealed that each genotype under study usually requires specific culture media components to regenerate effectively (Quresji and Saxena, 1992; Desilets et al., 1993; Wojtania and Gabryszewska, 2001). Moreover, particular genotypes respond differently to the type of plant growth regulators or their analogs supplemented to the medium. This is especially true for substances with cytokinin-like activity, as well as for their combinations with auxins or auxin-like compounds (Madden et al., 2005). Thus, it is of utmost importance to elaborate an in vitro culture protocol to induce and sustain the regeneration capacity of specific Pelargonium species, subspecies or cultivars. The goal of this study was to establish a tissue culture of the precious and attractive Pelargonium $\times$ domesticum cultivars. We focused, in particular, on obtaining a proliferative shoot culture of regal geranium and, consequently, healthy looking microcuttings ready to be rooted. The regenerated shoot leaf epidermis and anatomical features of newly obtained leaf blades were studied and compared. Our objective was to evaluate the effectiveness of the applied regeneration protocol and to gather some experimental data for future taxonomical comparisons.

\section{Materials and methods}

The plant material was obtained from the Botanical Garden in Prague (Botanická Zakrada hl. m. Prahy, Czech Republic). Pelargonium cultivars of hybrid origin obtained on the basis of Pelargonium grandiflorum which was kindly provided by Dr. Stolarczyk (University of Agriculture in Krakow) were used as donors to initiate the tissue culture. Plant material for excision of the primary explants represented Pelargonium $\times$ domesticum "Tip Top Duet" and "Black Knight" cultivars. The "Tip Top Duet" cultivar prefers sunny stands. It blooms from June to August, its flowers are two-colored, violet and pink, with a velvet appearance to its bright green leaves. "Black Knight" prefers shady stands, blooms from April to September, and its two-colored petals are dark violet and white. Its leaves are dark green.

\section{In vitro culture initiation}

First, a procedure for the surface disinfection of stem pieces was elaborated. Next, in order to initiate a culture from both studied cultivars, 40 primary explants were excised, with two explants constituting a single replicate. Primary explants for culture initiation were taken from the Pelargonium collection maintained under greenhouse conditions. Nodal segments about $10 \mathrm{~mm}$ long with lateral buds excised from young stems were surface sterilized by immersing in $70 \%$ ethanol $(60 \mathrm{~s})$, followed by immersion in $0.1 \%(\mathrm{v} / \mathrm{v})$ mercuric chloride solution containing Tween-80 (2 drops per $100 \mathrm{ml}$ ) (2 min). Explants were then thoroughly rinsed 5 times in sterile distilled water. Later, explants were transferred into initiation media $\mathrm{E}$ and $\mathrm{E}_{\mathrm{C}}$, which were composed of Murashige and Skoog mineral salts (1962) with doubled content of amino acids, and the media was supplemented with $30 \mathrm{~g} / \mathrm{l}$ sucrose. If required, the initiation media contained $0.05 \mathrm{mg} / \mathrm{l}$ indole-3-butyric acid (IBA) and $0.25 \mathrm{mg} / \mathrm{l}$ benzyladenine (BA) g/l, and were solidified with $0.8 \%$ Difco agar (Difco Laboratories Inc., $\mathrm{UK})$. Additionally, the $\mathrm{E}_{\mathrm{C}}$ medium contained $0.6 \mathrm{~g} / \mathrm{l}$ activated charcoal. Medium $\mathrm{pH}$ was adjusted to 5.8 prior to autoclaving at $0.122 \mathrm{MPa}$ for $20 \mathrm{~min}$. The shoots that developed were subcultured in the same medium. The cultures were indexed for growth and the possible mortality of explants due to visible bacterial contamination.

\section{Stage of vegetative propagation}

Shoots developed on the initiation media $\left(E / E_{C}\right)$ were transferred onto the propagation media $\left(\mathrm{P}_{\mathrm{K}}, \mathrm{P}_{1}, \mathrm{P}_{2}\right)$ listed in Supplementary Table 1. The main differences between particular treatments lay in the possible application of peptone, adenine, and plant growth regulators as well as in their dose. Secondary explants were taken from aseptic shoot cultures of respective cultivars which had been maintained in in vitro conditions. Such explants were $10 \mathrm{~mm}$ long apical shoot parts. Subculturing of cultivated organs was performed at four-week intervals. The culture was regularly documented. Simultaneously, basic biometrical data and anatomical features were recorded. Microscopic observations of regenerated leaf epidermis were performed with a light microscope (Nikon Eclipse 400), according to the procedure described elsewhere (Stolarczyk et al., 2013). The upper and lower epidermis was removed from the leaf blade and 
analyzed in relation to the type, structure, and length of trichomata. Calculations were made using Image ProPlus 4.0 software. The propagation coefficient, calculated as the number of new shoots developed from a single secondary explant, was assessed at the end of every passage.

\section{Growth conditions and statistical analysis}

Explants were cultured in $100 \mathrm{ml}$ Erlenmayer flasks filled with $25 \mathrm{ml}$ of culture medium. Cultures were maintained in a growth chamber, at the day temperature of $25^{\circ} \mathrm{C}$, and the night temperature of $20^{\circ} \mathrm{C}$, with a $16 / 8$ photoperiod. The culture environment was maintained at $80 \mu \mathrm{mol} / \mathrm{m}^{2}$ s of PPFD. Cool white fluorescent lamps were used as a light source. Experiments were organized according to a randomized design with 40 explants per treatment and two repetitions of the experimental unit. The results were subjected to a statistical analysis using the ANOVA module in STATISTICA ver. 10.0 software. A post-hoc Tukey test was used to study the differences between the means at $P<0.05$.

\section{Results and discussion}

During culture initiation, axillary buds of excised nodal segments slowly developed into shoots. However, the total number of regenerated shoots was reduced due to contaminations with latent bacteria, which was mainly apparent during the first passage (Supplementary Table 2). During the course of the initial culture, the activated charcoal supplementation did not influence either the quality or the regeneration efficiency of the shoot. Nevertheless, the number of viable explants was sufficient to initiate the culture (Supplementary Fig. 1) and to develop new leaves from buds. The aim of the next stage was to obtain a proliferative culture of regal geranium. Culture media used in the experiment (Supplementary Table 1) appeared to be appropriate to obtain successfully proliferating shoot culture. The regeneration efficiency proved to be similar for all media tested during the first passage, but varied in the successive passages (Supplementary Table 3). Microshoots obtained in every passage were intensely green, up to several millimeters high, and usually formed two or three new leaves (Fig. 1). As shown in Supplementary Table 3, the regeneration efficiency of Pelargonium $\times$ domesticum "Tip Top Duet" was slightly elevated in comparison to "Black Knight". During the proliferation stage, an addi-

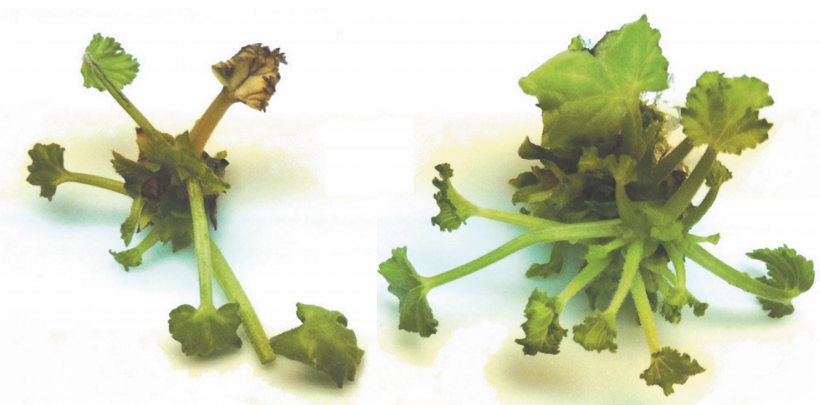

Fig. 1. Proliferation of Pelargonium "Tip Top Duet" shoots on modified MS proliferation medium without peptone (left) and with $100 \mathrm{mg} / \mathrm{l}$ of peptone (right)

tion of peptone to the medium was beneficial for the formation of new axillary buds, especially for the "Tip Top Duet" cultivar, even though after 14 days of culture the propagation coefficient was 21.5 for "Black Knight" and 22.2 for "Tip Top Duet". It was ascertained that the addition of $200 \mathrm{mg} / \mathrm{l}$ of peptone and $0.5 \mathrm{mg} / \mathrm{l}$ adenine to the culture medium resulted in a beneficial effect on the Pelargonium $\times$ domesticum "Tip Top Duet" culture. The highest propagation coefficient, exceeding 82 adventitious shoots from a single secondary explant, was obtained on a modified MS medium supplemented with $200 \mathrm{mg} / \mathrm{l}$ peptone and $0.5 \mathrm{mg} / \mathrm{l}$ adenine. Regenerated microshoots easily developed new leaves during the elongation stage. Fully expanded new leaves were analogical to those of a standard mother plant, with no spots or color changes. Apart from their small size, Pelargonium shoots resembled donor plants grown in greenhouse conditions (Supplementary Fig. 2). Leaves were anatomically properly formed and, especially in the lower epidermis, numerous trichomata were present. Those trichomata which were grandular consisted of two basal cells in the "Black Knight" cultivar and three in "Tip Top Duet" with clearly enlarged basal cells connected with the epidermis. The mean height of fully developed grandular hairs of Pelargonium $\times$ domesticum "Tip Top Duet" was $130 \mu \mathrm{m}$ and in "Black Knight" $124 \mu \mathrm{m}$, whereas non-glandular, unicellular hairs were 327 and $279 \mu \mathrm{m}$, respectively.

During culture initiation, some losses of studied cultivars due to bacterial contamination were observed. This is not unusual with cultures of Pelargonium and other taxa cultivated in vitro. For example, the results of an analysis conducted by Barett and Cassels (1994) revealed that endogenic infection with Xantomonas campestris pv. pelargonii could be indexed in explants taken 
from cultivars of Pelargonium $\times$ domesticum. Sekhar and Thomas (2015) isolated Fusarium oxysporum f. sp. cubense from shoot-tips of a banana cultivar. Only a few cultivars of Pelargonium $\times$ domesticum have been multiplied vegetatively in a tissue culture (Dunbar and Stephens, 1991; Vejsadová and Kuchtová-Jadrná 2009), and, in the current paper, in "Black Knight" and "Tip Top Duet". Articles published so far have enumerated the following cultivars of Pelargonium $\times$ hortorum: "Bargpalais", "Holywood Red”, "Grand Prix“, "Jazz Rocky Mountain”, "Orbit White”, "Scarlet Orbit”, "Red Elite”, "Ringo Rose", "Ringo Salmon", "White Rocky Mountain", and Pelargonium $\times$ hederaefolium - "Beach", "Bonete", "Luna", "Sofie Cascade", and such like (Desiltes et al., 1993; Murthy et al., 1996; Mithila et al., 2001; Wojtania and Gabryszewska, 2001; Wojtania, 2010; Wojtania et al., 2004; Madden et al., 2005), with petals having many colors, different foliage types and growth habits. In our experiments, we focused on the elaboration of a convenient propagation medium for Pelargonium $\times$ domesticum. Differences in trophic requirements at different stages of in vitro culture were shown. Further, when in vitro shoot fragments of studied cultivars were transferred onto media supplemented with peptone, organogenesis was prompted, especially in the "Tip Top Duet" cultivar. Peptone is frequently used as an additive in orchid tissue culture (Chen et al., 1999; Kaur and Bhutani, 2012 and herewith cited literature) with a beneficial effect on culture proliferation and morphogenetic response. This diffusible, soluble substance, obtained as a result of a partial hydrolysis of animal protein, is rich in amino acids and has proved to have a positive effect on other plant material, for example banana (Pervin et al., 2013) or purple foxglove (Hagimori et al., 1982). An important feature of the studied culture has been the dimensions of cells and the visual appearance of epidermis. The results of such observations were for the first time conducted in two Pelargonium $\times$ domesticum cultivars - "Black Knight" and "Tip Top Duet" - both valuable ornamental plants. It has been found that the structure of trichomata can be used as a taxonomic tool in systematic comparisons.

\section{Acknowledgements}

This study was financially supported by the Polish Ministry of Science and Higher Education in the form of DS 3500/ZBiFR. The financial support is gratefully acknowledged by the authors.

\section{References}

Bakker F.T., Culham A., Daugherthy L.C., Gibby M. (1999) $A$ trnL-F based phylogeny for species of Pelargonium (Geraniaceae) with small chromosomes. Plant Syst. Evol. 216: 309-324.

Bakker F.T., Culham A., Pankhurst C.E., Gibby M. (2000) Mitochondrial and chloroplast DNA-based phylogeny of Pelargonium (Geraniaceae). Amer. J. Bot. 87(4): 727-34.

Barett C., Cassels A.C. (1994) An evaluation of antibiotics for the elimination of Xantomonas campestris pv. pelargonii (Brown) from Pelargonium $\times$ domesticum cv. "Grand Slam" explants in vitro. Plant Cell Tiss. Org. Cult. 36: 169-175.

Chen J.T., Chang C., Chang W.C. (1999) Direct somatic embryogenesis on leaf explants of Oncidium Grower Ramsey and subsequent plant regeneration. Plant Cell Rep. 19: 143-149.

Darras A.I., Bali J., Argyropoulou E. (2015) Disease resistance and growth responses in Pelargonium $\times$ hortorum plants to brief pulses of UV-C irridiation. Sci. Hort. 181: 95-101.

Desilets H., Desjardins Y., Belanger R.R. (1993) Clonal propagation of Pelargonium $\times$ hortorum through tissue culture: effects of salt dilution and growth regulator concentration. Can. J. Plant Sci. 73: 871-878.

Dunbar K.B., Stephens C.T. (1991) Plant regeneration from callus-derived protoplasts of Pelargonium $\times$ domesticum. Plant Cell Rep. 10: 417-420.

Hagimori M., Matsumoto T., Obi Y. (1982) Studies of the production of Digitalis cardenolides by plant tissue culture. III. Effects of nutrients on digitoxin formation by shootforming cultures of Digitalis purpurea L. grown in liquid media. Plant Cell Physiol. 23(7): 1205-1211.

Kaur S., Bhutani K.K. (2012) Organic growth supplement stimulants for in vitro multiplication of Cymbidium pendulum (Roxb.) Sw. Hort. Sci. (Prague) 39(1): 47-52.

Lis-Balchin M., Deans S.G. (1996) Antimicrobial effects of hydrophilic extracts of Pelargonium species (Geraniaceae). Let Appl. Microbiol. 23(4): 205-207.

Madden J.I., Jones C.S., Auer C.A. (2005) Modes of regeneration in Pelargonium $\times$ hortorum (Geraniaceae) and three closely related species. In Vitro Cell Develop. Biol. Plant 41: 37-46.

Martinez-Cabrera H., Peres-Neto P.R. (2013) Shifts in climate foster exceptional opportunities for species radiation: the case of South African geraniums. PLoS ONE 8(12): e83087. doi: 10.1371./journal.pone.0083087

Milošević S., Cingel A., Jeremović S., Stankowić J., Bulajić A., Krstić B., Subotić A. (2012) Virus elimination from ornamental plants using in vitro culture techniques. Pesticid. Phytomed. 27(3): 203-2011.

Mithila J., Murch S.J., KrishnaRaj S., Saxena P.K. (2001) Recent advances in Pelargonium in vitro regeneration systems. Plant Cell Tiss. Org. Cult. 67: 1-9.

Mosina G.K.E., Maroyi A., Potgieter M.J. (2014) Comparative analysis of plant use in peri-urban domestic gardens of the Limpopo Province, South Africa. J. Ethnobiol. Ethnomed. 10: 35pp. www.ethnobiomed.com./content/10/1/35 
Moyo M., Van Staden J. (2014) Medicinal properties and conservation of Pelargonium sidoides D.C. J. Etnopharmacol. 152: 243-255.

Murashige T., Skoog F. (1962) A revised medium for rapid growth and bioassays with tobacco tissue cultures. Physiol. Plant 15: 473-497.

Murthy B.N.S., Singh R.P., Saxena P.K. (1996) Induction of high-frequency somatic embryogenesis in geranium (Pelargonium hortorum Bailey cv Ringo Rose) cotyledonary cultures. Plant Cell Rep. 15(6): 423-426.

Nejad A.R., Ismaili A. (2013) Changes in growth, essential oil yield and composition of geranium (Pelargonium graveolens L.) as affected by growing media. Sci. Food Agr. 94: 905-910.

Quresji J.A., Saxena P.K. (1992) Adventitious shoot induction and somatic embryogenesis with intact seedlings of several hybrid seed geranium (Pelargonium $\times$ hortorum Bailey) varieties. Plant Cell Rep. 11: 443-448.

Pervin R., Azam F.M.S., Morshed T., Rahman S., Hero K.A., Rahmatullah A.M. (2013) Natural growth substances has effective role in callus culture of banana (Musa spp.) cultivar "Anupman" (AAB Genome, Sapientum Subgroup). Amer. Eurasian J. Sust. Agri. 7(3): 149-154.

Rao R.B.R (2002) Biomass yield, essential oil yield and essential oil composition of rose-scented geranium (Pelargonium species) as influenced by row spacing and intercropping with cornmint (Mentha arvensis L. f. piperascens Malinv. ex Holmes). Indust. Crops Prod. 16: 133-144.

Rao R.B.R., Knaul P.N., Mallavarapu G.R., Ramesh S. (1996) Effect of seasonal climatic changes on biomass yield and terpenoid composition of rose-scented geranium (Pelargonium species). Bioch. Syst. Ecol. 24(7/8): 627-635.
Saraswathi J., Venkatesh K., Baburao N., Hilal M.H., Rani A.R. (2011) Pharmacological importance of Pelargonium species. J. Med. Plant Res. 5(13); 2587-2598.

Sekhar A.C., Thomas P. (2015) Isolation and identification of shoot-tip associated endophytic bacteria from banana $\mathrm{cv}$. Grand Naine and testing for antagonistic activity against Fusarium oxysporum f. sp. cubense. Amer. J. Plant Sci. 6: 943-954.

Stolarczyk P., Jurgielewicz M., Mermel K. (2013) Comparison of the morphological and anatomical structure of leaf of selected succulent species of Pelargonium genus. Episteme 20(2): 185-195 (in Polish).

van der Walt J.J.A., Vorster P.J. (1983) Phytogeography of Pelargonium. Bothalia 14(3-4): 517-523.

Vejsadová H., Kuchtová-Jadrná P. (2009) In vitro regeneration and polyploidy induction in Pelargonium $\times$ hortorum L.H. Bailey. A. Univ. Agric. Silv. Mendelianae Brun. Vol. 57(5): 305-312.

Weng M.L., Ruhlman T.A., Gibby M., Jansen R.K. (2012) Phylogeny, rate, variation, and genome size evolution of Pelargonium (Geraniaceae). Mol. Phylogenet. Evol. 64: 654-670.

Wojtania A. (2010) Effect of meta-topolin on in vitro propagation of Pelargonium $\times$ hortorum and Pelargonium $\times$ hederaefolium cultivars. Acta Soc. Bot. Pol. 79(2): 101-106.

Wojtania A., Gabryszewska E. (2001) Effect of cytokinin and amino acids on multiplication of Pelargonium cultivars. Acta Soc. Bot. Pol. 70: 203-207.

Wojtania A., Gabryszewska E., Marasek A. (2004) Regeneration of Pelargonium $\times$ hederaefolium "Bonete" from petiole explants. Acta Physiol. Plant. 26: 255-262. 